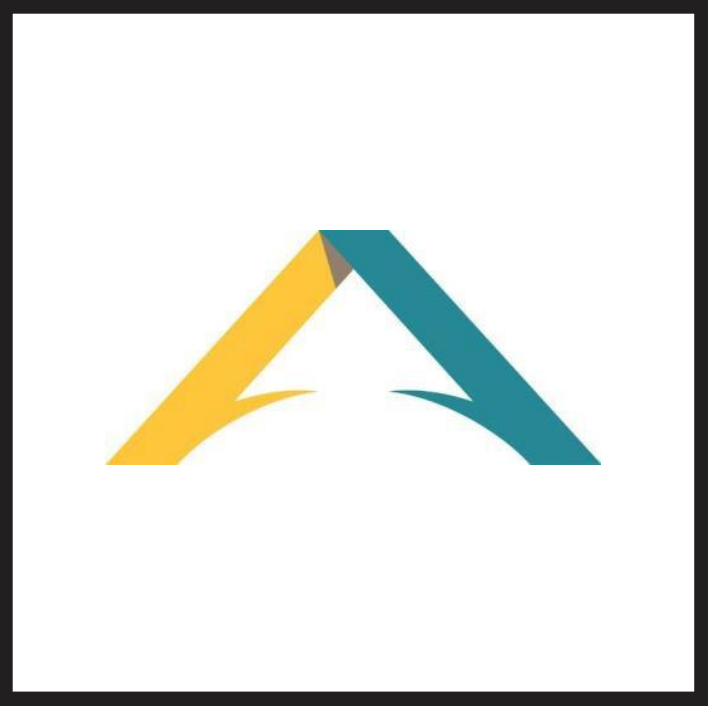

Revista

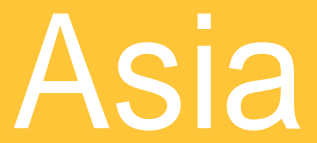

América

Latina

ISSN 2524-9347

Grupo de Estudios sobre Asia y América Latina Instituto de Estudios de América Latina y el Caribe Universidad de Buenos Aires

(c)

EU

DE BA 
The liberationist thinking in Oceania: cartography of circulation of Latin American ideas in the South Pacific

EDUARDO DEVÉS

Devés, Eduardo. "El liberacionismo en Oceanía: Una cartografía de circulación de ideas suramericanas en el Pacífico Sur”. Irquierdas, 49 (2020), 209-221.

\section{THE LIBERATIONIST THINKING IN OCEANIA: CARTOGRAPHY OF CIRCULATION OF LATIN AMERICAN IDEAS IN THE SOUTH PACIFIC ${ }^{1}$}

\section{Eduardo Devés}

Universidad de Santiago de Chile

eduardo.deves@usach.cl

ABSTRACT: The research consists of detecting the presence from the 1970s until the beginning of the 21st century, of two expressions of South American liberationist thinking (Paulo Freire's pedagogy and theology of liberation) in Oceania. Intellectual reception ecosystems and processes of circulation and re-elaboration are indicated in 4 intellectual spaces: higher education institutions (universities and religious seminaries), liberation movements, adult literacy, and indigenous peoples' organizations. Cases are detected in states and territories such as Australia, Fiji, New Caledonia, New Zealand, Papua New Guinea, Timor East, and Vanuatu. Finally, this research concludes with the characterization of the ways in which the South American ideas were received and re-elaborated and the channels through which they arrived in the region and through which they circulated within it.

KEYWORDS: Circulation of ideas, Liberationist thinking, Latin American thought, Paulo Freire, Oceania

RESUMEN: La investigación consiste en detectar la presencia desde los años 1970s hasta inicios del siglo XXI, de dos expresiones del pensamiento liberacionista suramericano (la pedagogía de Paulo Freire y la teología de la liberación) en Oceanía. Se indican los ecosistemas intelectuales de recepción y algunas de las formas de circulación y procesos de reelaboración. Ello se estudia en 4 espacios: las instituciones de formación superior (universidades y seminarios religiosos), los movimientos de liberación, la educación de adultos y las organizaciones de pueblos indígenas. Se estudian casos en Estados y territorios como

\footnotetext{
${ }^{1}$ Traducción al inglés hecha por Alejandro Lamarque y editada por Max Povse.
} 
The liberationist thinking in Oceania: cartography of circulation of Latin American ideas in the South Pacific

EDUARDO DEVÉS

Australia, Fiyi, Nueva Caledonia, Nueva Zelanda, Papúa Nueva Guinea, Timor Oriental y Vanuatu. Se concluye caracterizando las formas en que las ideas suramericanas fueron recepcionadas-reelaboradas y los canales a través de los cuales llegaron a la región y por los cuales circularon dentro de la misma.

Palabras Clave: Circulación de las ideas, Liberacionismo, Pensamiento latinoamericano, Paulo Freire, Oceanía

\section{Introduction}

Studies about ideas have barely ventured towards the Pacific, understood as the whole of the basin while disregarding the interior. Practically, the South Pacific region has not been a unit of analysis, notwithstanding few exceptions (Gardner, 2013; Vervoorn, 2005). Moreover, the Pacific is completely irrelevant among South American thought and its studies when compared to the importance of the Atlantic. Studies concerning South American thought have recently focused on studying connections with other regions of the world besides conventional relations with Western Europe (Bayle, 2015; Beigel, 2013; Devés, 2017). Nevertheless, spatial, and regional coverage remains scarce. Within this, the Pacific continues to be almost entirely absent, except for a few exceptions (Connelly, 1983; Devés, 2016; Rothwell, 2012; Zea, 1988). A first glance would insinuate that practically no circulation of ideas has existed, and that would lead to a major error since new approaches suggest numerous pointers. Moving forward in the task of studying the connections of comings and goings between the basin shorelines seems like an urgent necessity, especially for those willing to highlight non-Eurocentric dimensions in the circulation of ideas. The objectives of this research are, first and primarily, to determine in which intellectual milieus, of what nature, and in which States or territories, aspects of the south American liberationist ${ }^{2}$ thinking were received and cultivated; secondly, to determine where did such ideas came from, through which channels and if these were later exported and where to. In view of these objectives, this paper tries to offer a first cartography of circulation-settlement of ideas coming from South America between 1970, that is, since the liberationists (Paulo Freire and the theologists) published their first volumes, until a little over the 2000 s.

${ }^{2}$ Understanding liberationist thinking as the set of South American expressions inspired by the notion of liberation expressed in education, theology, philosophy, psychology, and sociology among others. Those interested in this thinking can see Cerruti, 2007; Silva, 2009; McKeever, 2004; Richard, 2002; Dussel, 1999; Gadotti, 1996; Libanio, 1992.

Asia/ América Latina, vol. 6, no 11, (2021), pp. 38-56. DOI: 10.33177/11.3 
The liberationist thinking in Oceania: cartography of circulation of Latin American ideas in the South Pacific

EDUARDO DEVÉS

This paper presents some cases, bearing in mind the different ambits of reception. It could not be exhaustive given the required length, but it aims to be merely indicative of what is happening with a South American eidetic tendency in the region, providing work criteria rather than a finished revision. It should be added that the earliest information has been prioritized given its greater interest.

The paper will follow a historical exposition bearing in mind grosso modo the order in which this presence is detected. Each case will be studied considering the following issues: persons, institutions, cities, most relevant years and connections with other figures and institutions to understand this eidetic circulation, giving voice to the protagonists in the reception and circulation of the ideas.

The hypothesis that organized this investigation was the existence of numerous intellectual niches in Oceania, where some ideas of South American origin had been received through a process of eidetic circulation energized by the World Council of Churches (WCC). As the conclusion of a more exhaustive investigation, this hypothesis is confirmed in good measure, although other cases are presented with diverse profiles, other networks, and "energizers", that is, instances that provided human and economic resources so that the circulations would be carried out. From this point forward, the surveyed cases are classified depending on the intellectual ecosystems receiving them: academic, university and seminary ambits, national liberation movements, indigenous movements, and educators in adult teaching. Such ambits and niches should be considered as interconnected because people belong to not just one of these, and, above all, because ideas circulate among them ${ }^{3}$.

\section{Universities and theological seminars}

A first ambit of reception can be identified in the theological seminars of diverse Christian denominations and various Oceanic universities. A very early case is revealed through the Vanuatuan John Sethy Regenvanu, member of a presbyterian denomination. In his biography Regenvanu, who was born in 1945 and held important positions in the politics of his country before and after the independence, tells how during his studies in Suva, Fiji, he shared the experience with teachers and students from varied educational institutions, such as the University of the South Pacific, where a small group of vanuatuans and people from the Christian Student Movement studied. He lived in Fiji in the 70s

\footnotetext{
${ }^{3}$ On this conceptualization and some of its developments, see Devés and Kozel (2018).
} 
The liberationist thinking in Oceania: cartography of circulation of Latin American ideas in the South Pacific

EDUARDO DEVÉS

as a student at Pacific Theological College ${ }^{4}$, where he had the chance to listen to Ivan Illich during his visit to Suva in 1972 (Gardner, 2013, p.135). Regenvanu writes:

Through these contacts and exchanges of ideas, I became increasingly interested in the problems affecting our society and eager to become actively involved in the changes. I began to learn about Father Walter Lini and his newspaper, New Hebrides Viewpoint, and on one occasion I even met him in Suva alongside Kalpokor Lasakau. These young men inspired me, and I saw them as leaders to work with for the good of the country. (2004, p.87)

Regenvanu narrates what happened on his return to Port Vila, Vanuatu, in 1974 and how he involved himself in the tasks of the Secretariat of Education at the presbyterian church where the missionaries William and Roxianne Coop worked. Ragenvanu highlights that working with them was particularly important for his development: "They motivated me to read extensively: editorials produced by colleagues from the Pacific islands, books about Third World countries, such as those texts by Julius Nyerere in Tanzania or the Liberation Theology in Latin America" (2004, p.88). Expounding on this, Regenvanu recalls he was shocked by the proposal of:

Self-reliance from President Julius Nyerere of Tanzania. I was equally impressed by the concepts of education for liberation and liberation theology developed by the Roman Catholics of Latin America, especially Doctor Paulo Freire. Freire, whose method and style of work with the politically and socially oppressed masses of Brazil, had particular significance for me. (2004, p.92-93)

The aforementioned indicates numerous hints leading to the WCC, which we know contributed to the motivation, organization, and financing of a set of initiatives in the region and its ecumenic activities in the different Christian denominations would manifest in the shipping of agents for the diffusion of Christianity, teachers for institutions, travel financing, publications, and scholarships, among others (Gardner, 2013). In addition, during those years Paulo Freire worked at the headquarters of the WCC in Bern. This becomes clearer with the fact that WCC sponsored Freire's trip to Oceania very early on,

4 "The Pacific Theological College is an ecumenical theological college located in Suva, Fiji. Established in 1965, it opened for training in 1966 and was originally designed as the only regional institution to offer degree-level education in theology, available primarily to students from Pacific Island churches". Taken from: www.http://ptc.ac.fj/. 
The liberationist thinking in Oceania: cartography of circulation of Latin American ideas in the South Pacific

EDUARDO DEVÉS

an occasion in which he would have participated in the conference on "Education for Liberation and Community" at Pacific Theological College in Suva (Gardner, 2013, p.135; Hassan, 1991, p.9), in activities in Australia and the Waigani Seminar at Papua NG in 1973. Places where his Pedagogy of the Oppressed, published in English in 1970, was already known.

The Vanuatuan John S. Regenvanu barely mentions the networks spreading South American ideas, rebuilding institutions and publications in the region. Nevertheless, a publication such as Melanesian Journal of Theology embodies these more thoroughly. This journal was edited in the city of Goroka, Papua New Guinea, within the activities of the Melanesian Institute and the Melanesian Association of Theological Schools. The Australian John D'Arcy May was the editor of this journal during its first era. Affiliated to the WCC, D'Arcy lived in Papua NG between 1983 and 1987, after having obtained a PhD in Theology at the University of Münster and another one in History of Religions in Frankfurt. In the presentation to the first issue of the journal, he underlined that the Melanesian Association of Theological Schools had decided to create "a journal with the specific purpose of developing an indigenous theology in Melanesia" (1985, p.2). Clearly, the journal "implies the use of English, which is both a barrier and an intermediary: it interferes due to its foreignness, just as it facilitates due to its universality. This dilemma is faced by all theologists of Third World" (1985a, p.3). Furthermore, he insisted on this orientation: "we aim to publish regularly literary reviews with special relevance to Melanesia, particularly in theological issues of the Third World" (1985b, p.4). Some of these ideas were further reinforced in a review written by D'Arcy himself commenting Walbert Buehlmann's book, The Coming of the Third Church. He states that:

a fascinating thing is that those different emphases and apparent contradictions have been addressed in a South/South discussion between theologists from each side, for instance, at the Ecumenical Association of Third World Theologians (EATWOT) forum and its journal $V$ oices of the Third World. We can look forward to the day in which Melanesians can make their own contributions to these discussions. (1985b, p.67)

In this context he repeatedly cites Hugo Assman, Juan Luis Segundo, and Leonardo Boff, as well as the Sri Lankan Aloysius Pieris, who published Asia Theology of Liberation and participated early on in the EATWOT meetings, and he also met him personally. It must be noted that EATWOT is the primary network that connected South American theological liberationism with the world. 
The liberationist thinking in Oceania: cartography of circulation of Latin American ideas in the South Pacific

EDUARDO DEVÉS

In parallel, by analysing the first issues of the Melanesian Journal of Theology it is possible to tell how the perspective, subjects, authors, and networks of south American liberationist thinking were recurrent among its editor and readers. Even more so, that there already was certain non-South American processing of the liberationist thinking, like considering subjects in terms of theologies of the Third World, theologies of the South and the issue of context, which do not properly pertain to the first stage of South American liberationist thinking. This, on the other hand, exposes the networks through which liberationist ideas would circulate, in some cases as a matter of activism in favour of these ideas, in other cases as a state of the art on theology. For example, Paul Richardson, a British resident in Popondetta, Papua, referred to Gustavo Gutiérrez:

who argues that liberation theology offers a new way to theology? This theology is much more self-conscious about its relationship to everyday struggles of Western theology. Even though European theology can be seen as a response to the pressures of society. (1985, p.62)

Laurenti Magesa's article, on the other hand, mentions the subject of liberation theology, as well as Gutiérrez and Leonardo Boff in reference to social sin and class struggle (1985, p.176-177). For his part, the Belgian Albert Bundervort, catholic bishop of Rabaul, Papua NG, argues that for evangelization to be effective "it must never go without the social and cultural context or life situation of those addressed by it. Therefore, liberation theology, just as it was elaborated in Latin America, is not and cannot be an article for export" (1958, p.183-183). Conversely, the journal is not without authors taking responsibility for the trajectory of oceanic figures that either knew South American liberationist thinking or had similar views such as John Momis, Walter Lini, Fred Timakata and Leslie Boseto. Esau Tuza writes:

On a social and religious level, John Momis and Leslie Boseto have spoken loud and clear. Momis, a religious catholic, considers involving himself with matters relative to social justice as part of his role as a priest. For him, it is in Papua NG's political arena where people's liberation must be considered. The church-state relationship has always been a hot topic of dialogue for Momis, for Walter Lini (Anglican) as well and Reverend Fred Timakata (Presbyterian) from Vanuatu, who fought to lead their peoples towards independence in 1980. (1985, p.52)

In this vein of studying expressions of liberationist thinking and its networks in Oceania's academic milieu, another figure that must be mentioned is the theologist Philip Gibbs, who exhibits a host of receptions, networks and reworks of South American liberationist thinking in those academic ambits. Born in 1947 in New Zealand, Gibbs obtained his doctorate in theology at 
The liberationist thinking in Oceania: cartography of circulation of Latin American ideas in the South Pacific

EDUARDO DEVÉS

Rome's Gregorian University, with a thesis revolving around The Word in the Third World. Divine Revelation in the Theology of Jean-Marc Éla, Aloysius Pieris and Gustavo Gutierre: Gibbs has dedicated numerous works to South American liberation theology as well as its derivations towards other places in the world and the resulting specific modulations $(1998 ; 2005 ; 2007)$, addressing the derivations from South America to Oceania on theological work. He argued in 1998 that "liberation theology is a recent attempt trying to integrate salvation and human effort, since it addresses salvation as an intra-historical reality where the political is grafted to the eternal" (1998, p.42). What Gibbs called "ferocious debate on liberation theology" is indicative, "of the diversity of opinions within the Catholic church". The underlines that:

In the past, conservative Evangelical and Pentecostal churches tended to considerer politics as a sinful world and kept distance. Nevertheless, there has been a significant change in Papua NG. Christians have accepted they must be a part in the answer to their prayers. This means they must become involved in political and social realities. (1998, p.42)

Following this he would quote dean Sherman who writes: "We are called upon to build and repair the damages to the walls of society through struggle, prayer and involvement". His call for involvement does not differ from the demand of commitment within liberation theology (1998, p.42). The New Zealander stressed in 2005 that "there are contextual theologies coming from many Third World countries that may stimulate ideas among the people of Papua NG. Theologists from Papua NG must make a significant contribution to EATWOT's work" (2005, p.51). Referring to Aloysius Pieris, creator of the "Asian liberation theology", he remarks that when talking about contextual theology "it is useful wondering just how much theological thought finds in the experience of faith among grassroot communities, what Pieris calls third magisterium" (2005, p.52). In 2007, Gibbs returned to this topics remarking that "over the last 30 years, there have been numerous attempts in various places around the world to include circumstance in theological thought", emphasizing that this circumstance is specific since "in Latin America, attention to political and social struggle against dependence and poverty has resulted in a form of theology in which 'liberation' has become the fundamental hermeneutical key to understanding the Christian message", whereas "in the Asia context, religious pluralism remains a constant challenge to contextual theology" and, "in Africa, theologies have focused on the ethnic and cultural dimensions of life in that continent. In the Pacific, there has been renewed attention develop a genuine contextual theology" (2007, p.4). 
The liberationist thinking in Oceania: cartography of circulation of Latin American ideas in the South Pacific

EDUARDO DEVÉS

\section{Popular and adult education}

A second space of reception-rework for South American liberationist thinking in Oceania was composed of those responsible for popular and adult education. Popular education is a privileged ambit and the most specific in terms of reception of Paulo Freire's ideas. In relation to this, various expressions may arise and three in particular: a first one, the most conventional, understood as the pedagogical work of professional educators; a second one, as indigenous education and overlapped with aboriginal people's organizations; and a third formula found in liberation movements, as will be observed in Timor. In this section, only the first one will be addressed, with the other two appropriately expounded on in the following parts.

The figure of Gwayeweng Kiki and his investigations, as part of his doctoral thesis under the guidance of Edmund Parker at Australia's Charles Sturt University, enables linking the presence of liberationist thinking in seminars and universities closely with adult education. Kiki, coming from Papua NG, has dedicated to the way of teaching theology to "non-Western" people. During a long residence at Suva's Pacific Theological College, he conducted research he characterized as oriented towards "a better and more efficient way of teaching theology to students in Papua NG within the Lutheran Evangelical Church" (Parker and Kiki, 2014, p.108). To frame and conduct his research, he systematically consulted Paulo Freire's work, just as he leaves written record of his work ${ }^{5}$. He has stressed that "an analysis of current teaching and learning methodologies used in the formation of Papua NG's Lutheran ministers was of particular importance", and it was supplemented with "praxis and transcultural learning, which shows ways of knowing and learning as they are used by people with non-Western orientations. In this vein, writers such as Paulo Freire were considered" as well as others. Thirdly, they highlight the "wokabaut-kaikulum notion, a 'concept' coming from tokpisin (a pidgin from Papua NG). In this view, non-aboriginal theorists of education, pedagogy and curricula were considered alongside aboriginal Melanesian specialists on culture, religion, and theology"

\footnotetext{
${ }^{5}$ For instance: Paulo Freire, Cultural Action for Freedom, preface by Joao da Veiga Coutinho (Middlesex: Penguin Education, 1974), and Pedagogy of the Oppressed, new rev. 20th-ann. ed. Translation by Myra Bergman (Ramos, New York: Continuum, 1997).
} 
The liberationist thinking in Oceania: cartography of circulation of Latin American ideas in the South Pacific

EDUARDO DEVÉS

(Parker and Kiki, 2014, p.109-110). His idea, aiming towards Melanesian epistemological systems, were innovative by trying to articulate Freire's thought with the Melanesian cultural trajectory, based on the wokabaut-karikulum which is defined as:

a shared relational approach to learning that emphasizes the relationship between learning and being, in the sense that mind and body are bound. But, on the other hand, knowledge obliges the individual in their relationship with the community, where the existence of knowledge is socially distributed. (Parker and Kiki, 2014, p.115)

The aforementioned research on theological education for adults is very recent, but Paulo Freire's impact on Oceania's adult education can be noticed since the early 70s. The South American visited Melbourne in 1972, invited as a speaker by the WCC. The argument has been made (Osmond, 2016) that his visit motivated a commitment among popular educators in the state of Victoria to adult education as a labour of social change, resulting in the permanence of concepts such as "emancipation" and "liberation" in this educator sector's discourse. This led to a set of pedagogical approaches such as: co-participation in learning, the notion of the teacher's task as a facilitator instead of an expert, the need of taking cues from the students' lives and experiences, student's involvement in the elaboration of learning goals and contents, and the presence of concepts such as emancipation and liberation in the discourse of those working as popular educators (Medlin, 2017; Osmond, 2016).

Precisely as an expression of the extensive legacy left by Freire in Australia, groups such as "Popular Education Network of Australia" and "Twenty First Century Critical Education" must be mentioned. The latter, composed of Tracey Ollis, Jo Williams, Rob Townsend, Anne Harris, Jorge Jorquera and Lea Campbell, states in its declaration of principles that:

Drawing on the philosophies and writings of Paulo Freire regarding education as activism, the network, founded in 2009, involves educators, academics, and community workers working together on issues relating to critical pedagogy and social change in schools, communities, and adult education contexts. (Ollis et al, 2010, p.175)

Afterwards, they remarked that the first symposium on Teaching and Learning for Social Justice and Action they organized "was held at Victoria University in October 2013 and focused on the ways in which popular education upholds a social justice agenda and functions within community development" (p.178) and that the fundamental address of the symposium "was done by 
The liberationist thinking in Oceania: cartography of circulation of Latin American ideas in the South Pacific

EDUARDO DEVÉS

Professor Antonia Darder and titled Reinventing Paulo Freire: A Critical Pedagogy of Love" (p. 179).

In this vein and continuing Freire's legacy, the gathering in 2012 of the "Australian Council of Adult Literacy" must be mentioned. The issue of the campaign addressed there was explicitly inspired in Paulo Freire's ideas, bearing in mind previous experiences such as Cuba, Tanzania, Nicaragua, Guinea Bissau, India, and East Timor, which will be specifically expounded on in the next section. In the Tasmania campaign report, presented by Bob Boughton (2012), Freire's work is systematically referred to in diverse regions of the world as well as authors referencing the Brazilian educator.

\section{Liberation movements}

A third ambit of reception is composed of the liberation or independence movements, particularly in East Timor and New Caledonia, as well as, but less explicitly, in Vanuatu. These were spaces where the ideas of South American liberationist thinking were received and even reformed jointly with others, present in those intellectual ecosystems, contributing to inspire those movements. Certainly, in diverse places the types of struggles for independence were also diverse, besides successful o failed, and so were the ideas of liberationist thinking that made it to those places. In some cases, it was mainly Freirean educational thought, in other cases it was associated with theological thought.

In East Timor, the WCC, generally very influential in the circulation of liberationist ideas, and the agents of the main acting churches in the region did not play salient roles. The circulation of liberationist ideas involved other networks here. A very different model of eidetic circulation is produced by Timorese students matriculated in some universities from Portugal and committed to independence and what would later become the Democratic Republic of Timor-Leste. In this case, independence organizations and guerrillas assumed Paulo Freire's arguments as methods to promote literacy and politization of the masses, all this through "Casa dos Timores", the student organization that brought them together in Lisbon. There, the literacy handbook "Timor is our country" was printed, created by the Revolutionary Front for an Independent East Timor (FRETILIN) combining the pedagogical and independence drive. Antonio Carvarinho and Francisco Borja, da Costa, among others, worked on this document (Leach, 2017, p.63-64). Nevertheless, "to make a whole literacy campaign possible, Silva (2012, p.2) remarks that FRETILIN, in association with the Portuguese Decolonization Committee, established the 
The liberationist thinking in Oceania: cartography of circulation of Latin American ideas in the South Pacific

EDUARDO DEVÉS

"Grupo de Coordenaçao para Reformulaçao do Ensino em Timor" (Urban, 2017, p.86). According to Silva (2011, p.63), among those participating in this literacy commission was Portuguese Professor Judith Magalhaes who, alongside the students from "Casa dos Timores" in Lisbon, was one of the persons that brought Paulo Freire's ideas on awareness to the Timorese Student National Union (Silva, 2012, p.2; Urban, 2017, p.86). Samuel Urban (2017) underlines that it was precisely "through this Portuguese committee that Paulo Freire's Pedagogy of the Oppressed arrived to Timor, becoming the starting point of the literacy campaign" and, eventually, "members of Casa dos Timores would take part in FRETILIN, also becoming 'trainers' (in the literacy campaign), together with people from other groups such as the Timorese Student Union and some people from the Portuguese Committee of Decolonization" (p.87).

A different case was that of New Caledonia's independence or autonomy movement, where it was the case of theological libertarianism, in the context of a network connected to Fiji, Vanuatu, Papua and the WCC, rather than the Timorese formula. Although, the similarity is noticeable in the struggle for independence and the reception of South American thought among student groups in foreign countries. The New Caledonian Pothin Wete created his most relevant work to this end as a postgraduate thesis at Suva's Pacific Theological College, as in the case of J. Regenvanu a decade before. In 1987 he presented his work there on the possibility of a kanak liberation theology ${ }^{6}$. Charles W. Forman (2005, p.118) argues that Wata reviewed the historical base of the political, economic, and social current situation of the kanak people and the evangelical church, tracing the emergence of ecclesial instances in favour of independence, referring to liberation theologies in other parts of the world and aiming towards a kanak theology of liberation. According to Forman, Wete brought "the liberation theme to a more fundamental level. He believes Kanak liberation theology will enrich and deepen the liberation theologies of other lands" (p.117). Since "this [theology] expresses the cry of a people not just for political or economic liberation but for their very existence" (p.117). As stated by Wete, kanaks would be "in danger of losing their existence through the loss of traditional values and the adoption of foreign ways" (p.117). And this concern is based:

not simply on national identity, it has biblical roots as well. The demand for independence flows from all that Hebrew prophets have said about

\footnotetext{
${ }^{6}$ Wete, Pothin. The development of the political awareness of the Kanak Evangelical Church in New Caledonia and the Loyalty Islands from 1960 to 1987 and its theological implications possibility for a Kanak liberation theology, Thesis (B.D.), Pacific Theological College, 1988.
} 
The liberationist thinking in Oceania: cartography of circulation of Latin American ideas in the South Pacific

EDUARDO DEVÉS

justice and freedom. It is also related to the Christian for the new creation. That hope leads the Kanaks forward on the path toward independence. (Forman, 2005, p.117)

Wete continued (Forman, 2005) a line that had already been cultivated in the same institution by another kana, Djoubelly Wea, who worked on an education for the liberation of the kanak people. ${ }^{7}$ After their studies, Wea above all, but also Wete, became involved with New Caledonia's independence and identity movements. Pothin Wete later became professor at Pacific Theological College, which shows the presence of a line of thought clearly related to South American liberationist thinking. In several other places of the South Pacific, important figures of the independence movements, several of these belonging to the clergy of diverse denominations as in the case of New Caledonia, had very similar positions and specifically inspired by liberationist thinking, just as was mentioned above: John Momis, Walter Lini, Fred Timakata and Leslie Boseto.

\section{Indigenous people's organizations}

The fourth space is constituted by the organizations of indigenous peoples. In this ambit, the cognizance of otherness regarding the Caucasian ethnicity, predominant in New Zealand and Australia, has taken place through Paulo Freire's notions. In this endeavour the figure of Graham HingangaroaSmith, a leader of Maori movements and professor at Auckland University, stands out. His most important approach to the issue has been Maori education and the coordination of this people with other indigenous ones surrounding the Pacific, besides the Oceanics, in places such as Canada, Hawaii, mainland US, Taiwan and Chile, which has linked him to the "Tribal Universities" project. Hingangaroa-Smith (2003) argues that the "counter strategy to hegemony is that indigenous people need to critically 'conscientize' themselves about their needs, aspirations and preferences" (p.2-3). He justifies: "this call for a 'freeing-up' of the indigenous imagination and thinking" since:

one of the elements of colonization is the diminishment of the indigenous ability to actually imagine freedom or a utopic vision free of the oppressor. Thus, a critical element in the 'revolution' has to be the struggle for our minds, the freeing of the indigenous mind. (p. 3)

He is looking, however, to articulate the discourse coming from Paulo Freire with the trajectory of indigenous thinking, what he denominates "Kaupapa

\footnotetext{
${ }^{7}$ Published in 1977: An Education for the Kanak Liberation: A Project, Pacific Theological College.
}

Asia/ América Latina, vol. 6, no 11, (2021), pp. 38-56. DOI: 10.33177/11.3 
The liberationist thinking in Oceania: cartography of circulation of Latin American ideas in the South Pacific

EDUARDO DEVÉS

Maori approach". This pertains to the fact that a predominant term such as "decolonization" is a "reactive notion", whereas "in moving to transformative politics we need to understand the history of colonization but the bulk of our work and focus must be in the imagination of a future" (p.3). In that sense, he points out "the lesson of the Kaupapa Maori approach from New Zealand is that transformation involves two parts: a confrontation with the colonizer and a confrontation with 'ourselves', the inside-out model, that splices with Freire's notion of "first free ourselves before we can free others" (2003, p.3). Hingangaroa-Smith has continued working on the Maori thinking-resistancepraxis based on Paulo Freire, as his subsequent publications in 2005 and 2009 show, but above all 2017, in which he returns to the subjects relative to Freire and conscientization. Besides Hingangaroa-Smith, other people working on the same issues in New Zealand can be included, such as Tangiwai Kepa, who presented her PhD. thesis at Auckland University in 2001. In Language matters: The politics of teaching immigrants adolescents school English, where she gives account of the perspective employed in her investigation remarking that "this thesis was written from the perspective of a Maori indigenous professor", who in spite of being "trained technocratic approaches of practices", has been "looking for aspects of her intimate culture, the ways of representing the world of Tonga and Samoa and Paulo Freire's critical pedagogy, to transform contemporary education, which tends to exclude the teenager from learning in school" (2001).

\section{Conclusions}

A first cartography of the presence of South American liberationist ideas in various places of Oceania has been offered. These are not the only ones. The number of intellectual ecosystems could be expanded and the niches where these ideas arrived and prospered could be better specified. It is a first account, done with pragmatic criteria and one that allows for some conclusions that will now be detailed.

Concerning the type of intellectual environments where the ideas were received and cultivated. Four primary ambits have been determined (academic ambits in universities and seminars, liberation and national independence movements, adult education spaces and indigenous people's organizations) in 7 South Pacific states or territories (Australia, Fiji, New Caledonia, New Zealand, Papua NG, East Timor, and Vanuatu). Such ambits are not completely separate and interact or even overlap. Oceania alone has been chosen in the search of homogeneity among the types of intellectual ecosystems, although other cases 
The liberationist thinking in Oceania: cartography of circulation of Latin American ideas in the South Pacific

EDUARDO DEVÉS

in the South Pacific could have been addressed. There are studies that account for the reception of Paulo Freire's thinking, particularly in the Philippines (Cortez, 2013; 2014) and Indonesia (Nuryatno, 2006). The Indonesian case would have been especially different since Freire's reception operates in intellectual ecosystems with autochthonous languages and marked by Islam.

Regarding the channels through which South American ideas arrived at different Oceanic intellectual ecosystems and if these were exported or circulated from there and where to. It follows that, since these are intellectual ecosystems where the languages of the intelligentsia are almost exclusively English and French, it is clear that communication was not always directly between South America and Oceania, not even in the case of East Timor where the language of the intelligentsia is Portuguese. In all cases circulation was partially mediated by networks and publishing houses in Western Europe and the US, as can be seen from the translation, the institutions, the networks.

This certainly does not exclude the agency of South American figures that worked in different places of the Pacific, especially some cities of Australia or New Zealand, or participated in relevant positions of international networks such as the case of Paulo Freire himself, as well as José Miguez Bonino and Julio Santa-Ana (Devés 2016; Paredes y Escalante Gómez, 2010) at the WCC, and above all, the creation and management of the EATWOT, crucial to the circulation of liberationist ideas among diverse places of the periphery world. More precisely, answering the issue of the networks that connected those receiving and the energizers of the circulation, the difference between theologists from Australia and New Zealand and those operating in the ecosystems of the islands ought to be underlined.

The former had circulation in the first world, connected relatively early to the EATWOT, and from there to people from South America and other provenances with knowledge of liberationism. Regarding the latter, first the institution of Fiji's Pacific Theological College in Suva and the network that articulated those who taught and/or studied there with other former students and with numerous people participating from diverse Christian denominations must be considered. The Pacific Theological College presents itself as probably the most important institution where the ideas of South American liberationist thinking were received, cultivated y re-exported in the South Pacific region. It has been seen how students and teachers from different backgrounds converged there and how, at least in some cases, these ideas were exported to New Caledonia, for instance.

Now then, if the energizers that consciously or not sustained the circulation of ideas, have historically been very diverse agents: states or empires, 
The liberationist thinking in Oceania: cartography of circulation of Latin American ideas in the South Pacific

EDUARDO DEVÉS

diplomacy, educational institutions, missionaries, propagandists, it must be remarked that in this case it was primarily churches and other civil society agents, notwithstanding the fact that in many cases economic resources depended on the states and their financing to churches and NGOs. In any case, one must not only imagine grand energizers that made circulation a possibility, but also numerous cases of people linked to popular education, to indigenous organizations, to politics, to university teaching, to ecclesial practices, among other activities, that were enthusiastic of these ideas and decided to transform into diffusers and "adapters" such as the case of adult education in Australia or East Timor.

\section{References}

APPLE, M. (1999). Freire, neo-liberalism and education. Discourse: studies in the cultural politics of education, 20(1), pp. 5-20.

BAYLE, P.A. (2015). Conectando sures. La construcción de redes académicas entre América Latina y África. Íconos, 53, pp. 153-170. DOI: http://dx.doi.org/10.17141/iconos.53.2015.1445

BEIGEL, F. (2013). Centros y periferias en la circulación internacional del conocimiento. Nueva Sociedad, $\mathrm{n}^{\circ} 245$. https:// nuso.org/articulo/centros-y-periferias-en-la-circulacioninternacional-del-conocimiento/

Boughton, B. (2012). South-South Cooperation: Can it work in Australia? Keynote Presentation Australian Council of Adult Literacy Annual Conference Hobart, Tasmania. 19-21 September 2012. New England University.

Bundervoet, A. (1985). Liberation Theology in the Context of Papua New Guinea. Journal of Melanesian Association of Theological Schools, 1(2), pp. 182185. Goroka.

CERUTTI, H. (2007). La filosofía de la liberación. México: FCE.

Connelly, M. (1983). Influencia del pensamiento de Mao en América Latina. Estudios de Asia y África, 18(2), pp. 215-231.

https:/ / estudiosdeasiayafrica.colmex.mx/index.php/eaa/article/view/ 883

Cortez, F.G.F. (2013). The Philippine Engagement with Paulo Freire. KRITIKE, 7(2), pp. 50-70. http://www.kritike.org/journal/issue_13/cortez_december2013.pdf 
The liberationist thinking in Oceania: cartography of circulation of Latin American ideas in the South Pacific

EDUARDO DEVÉS

Cortez, F.G.F. (2014). The Prospect of Liberating Pedagogy in the Thoughts of Amable G. Tuibeo. Mabini Review, 3(1), pp. 16-69. Polytechnic University of the Philippines.

http://dx.doi.org/10.4067/S0718-23762017000100213

DEVÉs, E. (2016). La circulación de las ideas, una conceptualización: el caso de la teología latinoamericana en Corea del Sur. Estudios Avanzados, 25, pp. $20-41$.

DEvÉs, E. (2017). La teología asiática de la liberación, un caso de recepción, apropiación y reelaboración de ideas. Universum, 31(1), pp. 213-230.

DEVÉs, E. Y KOZEL, A. (2018). Estudios Eidéticos. Una conversación, desde el sur, sobre la vida de las ideas y la reconfiguración de un espacio disciplinar. Santiago de Chile: Ariadna.

Dussel, E. (1999). Teología da Libertação. Um panorama de seu desenvolvimento. Petrópolis: Vozes.

Forman, C.W. (2005). Finding Our Own Voice: The Reinterpreting of Christianity by Oceanian Theologians. International Bulletin of Missionary Research, 29(3).

GadotTi, M. (1996). Paulo Freire uma biobibliografía. Sao Paulo: Cortez Editora. Gardner, H. (2013). Praying for Independence. The Presbyterian Church in the Decolonisation of Vanuatu. The Journal of Pacific History, 48(2), pp. 122-143. DOI: https://doi.org/10.1080/00223344.2013.781761

GIBBS, P. (1998). The Religious Factor in Papua New Guinea Politics. Catalyst, 28(1), pp. 27-51.

GIBBS, P. (2005). Grassroots in Paradise: Contextual Theology for Papua New Guinea. Melanesian Journal of Theology, 21(1), pp. 37-62.

GiBBS, P. (2007). Narrative and Context in a Practical Theology for Papua New Guinea. Australian eJournal of Theology, 9.

Hassan, G. (1991). Church and state in Vanuatu 1945-1980: A "Pacific" contest for power. South Pacific Journal of Mission Studies.

KEPA, T. (2001). Language matters: The politics of teaching immigrant adolescents school English. PhD. Thesis, Auckland University.

LEACH, M. (2017). Nation-Building and National Identity in Timor-Leste. London and New York: Routledge.

LiBAnio, J.B. (1992). Panorama da teología da América Latina nos últimos 20 anos. Perspectiva Teológica, 24(63), pp. 147-192. 
The liberationist thinking in Oceania: cartography of circulation of Latin American ideas in the South Pacific

EDUARDO DEVÉS

MAGESA, L. (1985). Instruction on the "Theology of Liberation": A Comment. Journal of Melanesian Association of Theological Schools. 1(2), pp. 175-181. Goroka.

MAY, J.D. (1985a). Editorial: Introducing MJT. Journal of Melanesian Association of Theological Schools. 1(1), pp. 1-3. Goroka.

MAY, J.D. (1985b). Theologies of the "Third Church". Journal of Melanesian Association of Theological Schools. 1(1), pp. 65-70. Goroka.

McKeEver, M. (2004). Thirty years of liberation theology. Theology Digest, 51.

MEDLIN, J. (2017). The Australian literacy and numeracy workforce: a literature review. Occasional paper. Adelaide: NCVER.

Nuryatno, M.A. (2006). Education and Social Transformation: Investigating the Influence and Reception of Paulo Freire in Indonesia. Ph.D. Thesis Faculty of Education, McGill University.

Ollis, T.; Williams, J.; TOWNSEnd, R.; HARris, A.; JORQUERA, J. AND CAmpBeld, L. (2010). The Popular Education Network of Australia (PENA) and Twenty-First-Century Critical Education in Peters, M.A. and Besley, T. (Eds.), Paulo Freire. The global legacy (pp. 175-186). Berlin: Peter Lang Publishing Books.

OSMOND, P. (2016). What happened to our community of practice? The early development of adult basic education in NSW through the lens of professional practice theory. Literacy and Numeracy Studies, 24(2), pp. 3-

23. DOI: http://dx.doi.org/10.5130/lns.v24i2.4821

PAREDES, A. AND ESCALANTE GÓmEZ, E. (2010). La visualización de "colegios invisibles" en las publicaciones político-religiosas de editorial Tierra Nueva (década 1970) y su inserción en discursos de época. Theoria, 19(1), pp. 61-82. Universidad del Bío-Bío.

PARKER, E. AND KIKI, G. (2014). Is There a Better Way to Teach Theology to Non-Western Persons? Research from Papua New Guinea that Could Benefit the Wider Pacific. Australian eJournal of Theology, 21(2), pp. 108124.

Regenvanu, J. (2004). From Village to Nation: an Autobiography. Institute of Pacific Studies and Emaulus Campus. Suva: University of the South Pacific.

https://books.google.cl/books?id=0WEeYDxeE9gC\&printsec=frontcover\&h $\mathrm{l}=$ es\&source $=\mathrm{gbs}$ ge_summary_r\&cad $=0 \# \mathrm{v}=$ onepage $\& \mathrm{q} \& \mathrm{f}=$ false 
The liberationist thinking in Oceania: cartography of circulation of Latin American ideas in the South Pacific

EDUARDO DEVÉS

Richardson, P. (1985). Seeing Western Theology in Context. Journal of Melanesian Association of Theological Schools. Vol 1(2), pp. 61-65. Goroka.

Richard, P. (2002). La Iglesia y la Teología de la Liberación en América Latina y el Caribe: 1962-2002. Pasos 103.

Rothwell, M. (2012). Transpacific Revolutionaries: The Chinese Revolution in Latin America. Routledge.

Schugurensky, D. (2014). Paulo Freire. London: Bloomsbury.

SiLVA, S. (2009). La Teología de la Liberación. Teología y Vida, Vol. L, pp. 93116. DOI: http://dx.doi.org/10.4067/S0049-34492009000100008

SILVA, A.B. DA (2011). FRETILIN Popular Education 1973-1978 and its relevance to Timor-Leste today. PhD. Thesis, New England University.

SILVA, A.B. DA (2012). Literacy Model of the Maubere Pedagogy. Comunicação apresentada no Grupo de Estudos Brasil-Timor, Peace and Conflict Studies Institute.

SMITH, G.H. (2003). "Indigenous Struggle for the Transformation of Education and Schooling, Keynote Address to the Alaskan Federation of Natives Convention". Alaska: Anchorage.

SMITH, G.H. (2009). Mai i te maramatanga, ki te putanga mai o te tahuritanga: From Conscientisation to transformation in Andrzejewski, J.; Baltodano, M.P and Symcox, L. (Eds.) Social Justice, peace and environmental education: transformative standards (pp. 19-28). New York and London: Routledge.

Smith, G.H. (2015) "Equity as Critical Praxis: The Self-Development of Te Whare Wananga o Awanuiarangi” en Peters, M y T. Besley, Paulo Freire: The Global Legacy (Eds.) Peter Lang, New York.

SmitH, G.H. (2017). "Keynote address: 12 noon, Wednesday, July 26, University Theatre (ADM026) Academic Work as Transforming Praxis: From Discourse to Enactment (Show me the blisters on your hands!)". http:/ /rmooc.ca/news/july-26-keynote-130-pm-graham-hingangaroasmith/

TuZA, E. (1985). Instances of "God-talks" in Melanesia. Journal of Melanesian Association of Theological Schools. 1(1), pp. 47-60. Goroka.

Urban, S. (2017). Paulo Freire e a educação popular em Timor-Leste: uma história de libertação. Educação e Emancipação, 10(1), pp. 76.

DOI:10.18764/2358-4319.v10n1p76-100 
The liberationist thinking in Oceania: cartography of circulation of Latin American ideas in the South Pacific

EDUARDO DEVÉS

Asia

Anerica

Latina

56

Vervoorn, A. (2005). Intelectuales públicos en Asia y el Pacífico. Anuario Asia Pacífico, n¹, pp. 461-470.

WETE, P. (1988). The development of the political awareness of the Kanak Evangelical Church in New Caledonia and the Loyalty Islands from 1960 to 1987 and its theological implications possibility for a Kanak liberation theology. Thesis (B.D.), Pacific Theological College.

ZEA, L. (1988). "Prólogo" a Rizal, José Noli me Tangere, Biblioteca Ayacucho, Caracas. 

